\title{
Понятие принципов международного экономического права
}

\section{Чабаева И.С. ${ }^{*}$}

В статье раскрывается понятие принципов международного экономического права. Рассматриваются подходы отечественных и зарубежных авторов по поводу рассмотрения принципов МЭП в качестве правовых режимов и стандартов, а также доводы отдельных авторов о невозможности подобного рассмотрения. Приводится перечень принципов МЭП, который не является исчерпывающим, а также международные документы, в которых закрепляются или конкретизируются рассматриваемые принципы. Анализируется вопрос о правомерности применения категории «экономический суверенитет». Отражаются существующие позиции о признании за отмеченными документами юридической обязательности или рекомендательного характера и возникающие в связи с этим вопросом высказывания о «мягком» праве, которое в доктрине обозначается различными терминами; а также вопрос о том, являются ли содержащиеся в этих документах принципы МЭП императивными. Рассматривается вопрос о формах выражения принципов МЭП, которыми являются международный договор и международный обычай.

Ключевые слова: понятие принципов международного экономического права; обычно-правовые и договорные принципы; международные акты, закрепляющие принципы и относящиеся к решению вопроса об их юридической силе.

Основные (общепризнанные) принципы международного права образуют основу для возникновения принципов и норм во всех сфеpax международных отношений, в том числе в сфере международных экономических отношений, поскольку они являются критерием «законности других норм, вырабатываемых государствами в сфере международных отношений» ${ }^{1}$, осуществляют их регулирование и через специальные отраслевые принципы способствуют формированию отрасли

\footnotetext{
* Чабаева Индира Султановна - аспирант кафедры международного права Московской государственной юридической академии им. O.Е. Кутафина. INDIRA.CHABAEVA@ ya.ru.

${ }^{1}$ Курс международного права. Т. 2. С. 12-13.
} 
международного экономического права (далее - МЭП). Такое качество основных принципов международного права обусловлено такими их свойствами, как императивность, высокая степень нормативного обобщения, общепризнанность, всеобщность, системность. Динамичное развитие международных экономических отношений и основанного на них сотрудничества привело к необходимости эффективного международно-правового регулирования данной области отношений и, как следствие, способствовало возникновению и развитию наряду с основными (общепризнанными) принципами международного права, играющими важную роль в регулировании международных экономических отношений, специальных (отраслевых) принципов международного экономического права, которые имеют существенное значение для развития правового регулирования международных экономических отношений и становления международного экономического права как самостоятельной отрасли международного права. К ним относятся: принцип экономической недискриминации; принцип экономического сотрудничества; принцип неотъемлемого суверенитета государств над их богатствами, ресурсами и экономической деятельностью; принцип свободы выбора форм организации внешних экономических связей страны, принцип запрещения применения противоправного экономического принуждения; принцип мирного урегулирования международных экономических споров; принцип взаимной выгоды; принцип взаимности; принцип наибольшего благоприятствования; принцип преференциального режима; принцип национального режима.

В отношении принципа наибольшего благоприятствования, принципа взаимности, принципа преференциального режима, принципа национального режима существует мнение о договорном характере названных принципов, то есть они приобретают обязательную силу для государств при условии их включения в конкретные договоры или в законодательство (принцип взаимности) ${ }^{2}$.

${ }^{2}$ См.: Ашавский Б. М. К вопросу о международном экономическом праве// Советский ежегодник международного права. М.: Наука, 1984. Выпуск 1986; Рулько Е.Т., Войтович С. А. Роль императивных норм в организации системы международного права//Советский ежегодник международного права. М.: Наука, 1983. Выпуск 1984; Ковалев А.А. Международное экономическое право и правовое регулирование международной экономической деятельности. Учебное пособие. М.: научная книга, 2007; Комарова Л.А. Международно-правовые принципы и формы экономического сотрудничества государств. М., 1986. 
Некоторые авторы рассматривают данные положения не в качестве принципов, а как правовые режимы или стандарты.

По мнению Г. Шварценбергера, подобные положения необходимо отнести к категории «стандартов» - неких юридико-технических критериев, по которым строится материальное внутреннее право. Они выводятся, прежде всего, из международно-договорного регулирования императивных или диспозитивных норм. Такими стандартами, по выражению автора, являются стандарты: взаимности, наибольшего благоприятствования, национального режима, открытых дверей, предоставления преференций, справедливости, минимального стандарта для иностранцев, если не реализуется принцип национального режима 3 .

Применительно к вышесказанному было бы уместно привести взгляд В.М. Шумилова, который предлагает говорить о международно-правовом режиме предоставления, например, национального режима применительно к МЭП (и, следовательно, о принципе предоставления национального режима $)^{4}$.

В.М. Шумилов, восприняв идею Г. Шварценбергера о существовании принципов-стандартов в МЭП, предлагает обозначить некоторые специальные принципы МЭП как принципы - методы сопоставления и уравнивания условий, способ организации отношений, технико-правовой инструментарий (своего рода «трафареты», «стандарты») и одновременно содержательные нормы. С его точки зрения указанные «стандарты» - универсальны, так как являются принципами всего международного права. В такую особую группу специальных принципов автор относит: принцип наибольшего благоприятствования, принцип предоставления национального режима, принцип экономической недискриминации и другие. Так, по мнению автора, принцип недискриминации требует уравнивания условий в сравнении с общими условиями; принцип наибольшего благоприятствования - в сравнении с наилучшими условиями; принцип национального режима требует уравнивания с условиями, созданными для внутренних (т.е. национальных) субъектов права 5 .

\footnotetext{
${ }^{3}$ Schwarzenberger G. The principles and standards of international economic law. Hague, 1981. Р. 53, 71.

${ }^{4}$ Шумилов В. М. Международно-правовое регулирование международных экономических отношений (Вопросы теории и практики)// Государство и право. 2000. № 7. С. 83. ${ }^{5}$ Шумилов В. М. Введение в российскую научную концепцию международного экономического права// Юрист - международник. 2003. № 1. С. 21; Он же. Международное экономическое право: Учебник. Ростов-на-Дону: Феникс, 2003.
} 
Г.М. Вельяминов, не соглашаясь со Г. Шварценбергером и В.М. Шумиловым, пишет, что понимание специальных принципов МЭП как принципов-стандартов может ввести в заблуждение, поскольку для стандарта характерна строгая определенность «стандартных» требований, а конвенционные принципы, конкретные условия которых обусловливаются индивидуально в каждом отдельном случае, таким свойством не обладают. «Нестандартность» специальных принципов МЭП, но их исключительная гибкость, по мнению Г.М.Вельяминова, может быть проиллюстрирована на практике применением принципа наибольшего благоприятствования. Данный принцип носит договорный характер и подразумевает свободу усмотрения сторон при его установлении; государства в каждом конкретном случае четко оговаривают все исключения из данного режима.

Иногда высказывается также точка зрения (Г.К. Дмитриева) о необходимости рассмотрения не принципов, а правовых режимов, поскольку режимы не являются общеприменимыми и действуют только тогда, когда заинтересованные государства договорятся об этом 6 .

В связи с этим ряд авторов считают неприемлемым противопоставлять «принципы» и «режимы» ${ }^{7}$. Так, в правовом своем значении принцип - это правовая норма (или комплекс норм), а режим в теории права понимается как «порядок регулирования, который выражен в многообразном комплексе правовых средств, характеризующих особое сочетание взаимодействующих между собой дозволений, запретов, а также позитивных обязываний и создающих особую направленность регулирования» ${ }^{8}$. Некий «режим», не привязанный к конкретным принципам (нормам), оказывался бы в правовом вакууме9.

Э.Л. Кузьмин, соглашаясь с мнением Г.М. Вельяминова, на примере режима наибольшего благоприятствования объясняет невозможность раздельного рассмотрения «принципов» и «режимов» тем, что общеприменимый характер данного режима вытекает из положений ГАТТ и договорное происхождение тех или иных международно-правовых норм не исключает обретения ими при определенных обстоятельствах статуса принципов, в том числе императивного характера. К тому же,

${ }^{6}$ Международное публичное пра $\neg$ во / отв. ред. К. А. Бекяшев. М., 2004. С. 420.

${ }^{7}$ См.: Вельяминов Г. М. Международное экономическое право и процесс (Академический курс): Учебник. М.: Волтерс Клувер, 2004; Международное публичное пра $\neg$ во / отв. ред. К. А. Бекяшев. М., 2008.

8 Алексеев С.С. Теория права. М., 1999. С. 373.

9 Вельяминов Г. М. Международное экономическое право и процесс. С. 136. 
по мнению автора, «понятия принципов взаимности, национального и преференциального режимов тождественны понятию «режим», поскольку затрагивают одно и то же явление - специфические условия, на которых государства выстраивают свои отношения в торгово-экономической сфере (хотя, разумеется, упомянутые принципы-режимы имеют различное субстантивное наполнение)» ${ }^{10}$.

Л.П. Ануфриева и А.А. Спектор связывают разделение принципов и режимов, производимое отдельными авторами, с субъективностью подхода, его скороспелостью и, в общем-то, надуманностью квалификаций. Авторы пишут в связи с этим, что «принципы международного экономического или торгового права, будучи таковыми (т.е., с одной стороны, нормами международного права, с другой - не простыми нормами, но правилами поведения, которые имеют основополагающий характер, - принципами), согласованы субъектами международного права и существуют, следовательно, именно как продукт договоренностей, зачастую достигнутых между государствами» ${ }^{11}$. Нет ясности, по их мнению, и в другом отношении: если и принципы, и режимы порождены согласованием, то почему одни нормы являются принципами, а другие, также возникшие из этого процесса, - режимами?»12.

В МЭП отсутствует четкий перечень принципов данной отрасли и даются различные их формулировки. Различие подходов объясняется тем, что МЭП является быстро развивающейся отраслью международного права, и система ее принципов также находится в постоянном развитии, вследствие чего каждый существующий принцип может наполняться новыми содержательными гранями, а также возникать новые принципы.

Формой выражения отраслевых принципов является как международный договор, так и международно-правовой обычай. Это говорит о том, что они могут существовать как самостоятельные нормы международного экономического права. Специальные принципы не могут противоречить основным принципам международного права, ибо они конкретизируют последние применительно к особой области - международным экономическим отношениям, - поэтому наделяются чертами, корреспондирующими основным принципам международного права.

10 Кузьмин Э. Л. Международное экономическое право: учебное пособие. М., 2008. C. 47.

11 Ануфриева Л.П., Спектор А.А. Принцип национального режима в регулировании международной торговли//Журнал российского права. 2007, № 10. С. 4.

12 Там же. 
Принципы международного экономического права нашли свое закрепление в таких многочисленных важнейших многосторонних актах, как Женевские принципы, принятые на первой конференции ЮНКТАД в Женеве в 1964 г. (Принципы международных торговых отношений и торговой политики, способствующие развитию), Декларация об установлении нового международного экономического порядка и Программа действий по установлению нового международного экономического порядка от 1 мая 1974 г. ${ }^{13}$, Хартия экономических прав и обязанностей государств от 12 декабря 1974 г. ${ }^{14}$, Заключительный акт Совещания по безопасности и сотрудничеству в Европе 1975 г,, Лимская декларация по промышленному развитию и сотрудничеству 1975 г., Сеульская декларация о прогрессивном развитии принципов международного публичного права, относящихся к новому международному экономическому порядку 1986г., резолюции Генеральной ассамблеи ООН «О мерах укрепления доверия в международных экономических отношениях» 1984 г. и «О международной экономической безопасности» 1985 г. и другие соответствующие решения Генеральной Ассамблеи ООН, ЮНКТАД и ЮНИДО.

Перечисленные международные акты содержат в себе совокупность специфических правил поведения международного общения, направленных на регулирование международных (межгосударственных) экономических отношений. Некоторые из этих принципов на универсальном уровне существуют в форме международно-правового обычая. Те специальные принципы, которые еще не обладают качеством общепризнанности, могут стать таковыми при соответствующих условиях либо договорным путем, либо путем формирования международно-правового обычая.

Упомянутые документы не являются юридически обязательными, а представляют лишь рекомендации, которые государства вправе применять для регулирования международных экономических отношений по своему усмотрению. В связи с таким положением в международноправовой доктрине закономерно возникает вопрос - являются ли содержащиеся в резолюциях Генеральной Ассамблеи ООН принципы

13 Декларация об установлении нового международного экономического порядка/Док. OOH. A/ Res/3201(S -VI) от 1 мая 1974 г.

${ }^{14}$ Принята 12.12.1974 Резолюцией 3281 (XXIX) на 2315-ом пленарном заседании 29ой сессии Генеральной Ассамблеи ООН/Док. ООН. А/Res/3281 (XXIX) от 12 декабря 1974 г. 
и нормы международного права, регулирующие международные экономические отношения, обязательными или они носят лишь рекомендательный характер. В этом плане существуют различные мнения как в отечественной международно-правовой доктрине, так и в зарубежной. Все существующие точки зрения можно разделить на три группы.

К первой группе можно отнести ученых, которые придерживаются позиции о безусловной юридической обязательности резолюций Генеральной Ассамблеи ООН. Данная концепция не имеет нормативного обоснования и не соответствует положениям Устава ООН, поэтому ее следует признать расходящейся с общепринятыми постулатами современной международно-правовой науки и практики.

Во вторую группу должны быть включены авторы, по мнению которых обязательное значение имеют те принципы и нормы МЭП, содержащиеся в резолюциях Генеральной Ассамблеи ООН, которые воспроизводят действующие международно-правовые нормы, в том числе устанавливают наличие обычно-правовой нормы, даже если такие положения не принимаются единогласно. Иными словами, положения, выведенные для регулирования международных экономических отношений из общепризнанных принципов международного права, носят императивный характер. В качестве примера можно привести принцип суверенитета государств над естественными ресурсами, богатствами и экономической деятельностью, закрепленный в Резолюции Генеральной Ассамблеи ООН от 12 декабря 1962 г. «О постоянном суверенитете над естественными ресурсами», а также в ст. 2 Хартии экономических прав и обязанностей государств 1974 г. Данный принцип, будучи специальным принципом международного экономического права, является производным от общепризнанного принципа уважения государственного суверенитета и направлен на регулирование международных отношений в экономической сфере. В международно-правовой литературе данный принцип формулируется как принцип уважения экономического суверенитета государств ${ }^{15}$. Не оспаривая

${ }^{15}$ См. в этой связи: Блищенко И. П., Дориа Ж. Экономический суверенитет государства: Учебное пособие. - М.: Изд-во РУДН, 2001; Мамедов Р.Ф., Абиев Р.С. Международно-правовые принципы реализации экономического суверенитета Азербайджанской республики//Евразийский юридический журнал. № 4 (11), 2009; Иванов И.М. Международно-правовое содержание экономического суверенитета//Евразийский юридический журнал. 2009, № 8. С. 33 - 38. Данная категория нашла свое отражение и в ст. 6 Ф3 «Об основах государственного регулирования внешнеторговой деятельности» от 08.12.2003 № 164 - ФЗ (в ред. от 02.02.2006). 
в целом квалификации и статуса названной нормы как специального принципа международного экономического права (причем одного из важнейших!), здесь уместно было бы поставить вопрос о правомерности введения в научный оборот такого термина и отстаивания соответствующей ему правовой категории «экономического суверенитета», поскольку, на наш взгляд, суверенитет может и должен быть единым и неделимым - государственным (национальным) и его объем не может быть добровольно или принудительно ограничен за счет международных договоренностей ${ }^{16}$. Между тем как в зарубежной, так и в отечественной литературе по международному праву настоятельно предлагаются позиции в пользу существования «экономического суверенитета». По мнению И.П. Блищенко и Ж. Дориа, необходимость эффективной реализации основных принципов международного права в международной экономической сфере и потребность в их международно-правовом закреплении привели к росту самостоятельного значения понятия экономической независимости, как элемента содержания государственного суверенитета, а также связанных с ним аспектов понятия равноправия в межгосударственных экономических отношениях. Исходя из этого, авторы при определении государственного суверенитета обращают внимание на ряд характерных его признаков. Во-первых, понятие экономического суверенитета является условным и презюмирует совмещение в его содержании собственно понятие суверенитета и понятие равноправия в межгосударственных экономических отношениях. На наш взгляд, было бы правильнее рассматривать понятия «суверенитет» и «равноправие» отдельно друг от друга. Несмотря на их тесную взаимосвязь, которая отражена в принципе суверенного равенства, суверенитет ipso facto присущ каждому государству с момента его образования и является более широким понятием по отношению к равноправию, которое включается в него, а равноправие есть юридическое равенство суверенных государств, независимо от уровня развития социально-экономических систем.

Во-вторых, экономический суверенитет - это не суверенитет в экономической области, а суверенитет экономического содержания в межгосударственных отношениях в целом. По нашему мнению, всякая

16 О сужении суверенитета говорит, в частности, Х.Х. Избулатов. Экономический суверенитет России в условиях нового геополитического порядка: Юридические формы реализации. Автореферат диссертации на соискание ученой степени кандидата юридических наук. Ростов-на-Дону, 2007. С. 6. 
правовая категория, в том числе и суверенитет, наполнена юридическим содержанием и поэтому так называемое «экономическое» содержание суверенитета вызывает закономерные возражения. Кроме того, если «принцип уважения экономического суверенитета, как пишут авторы, применяется не только в международном экономическом праве, но и в других отраслях МП», возникает вопрос о том, в каких же областях применяется принцип уважения государственного суверенитета как основополагающая норма общего международного права? На него, как представляется, в свете предложенной концепции невозможно найти ответ.

Наконец, утверждается, что понятие экономического суверенитета не связано с уровнем социально-экономического развития государств, так как экономически суверенными являются как развитые, так и слаборазвитые государства.

В данном случае следует отметить, что авторы, с одной стороны, понимают экономический суверенитет как совокупность экономической независимости и равноправия, а с другой, - используют экономический суверенитет и экономическую независимость как синонимы ${ }^{17}$, хотя последняя является составной частью «экономического» суверенитета. Однако далее в своей работе авторы отмечают, что термин «экономическая независимость» многозначен, поэтому предпочтительнее употреблять термин «экономический суверенитет», так как последний указывает на связь с суверенитетом государства либо в качестве элемента его фактического содержания, либо в качестве субъективного права государства, основанного на норме международного права. Подобное положение подтверждается определением, которое дают авторы понятию «экономического суверенитета» ${ }^{18}$, нормативное содержание которого включает два основных элемента: суверенное право государства свободно распоряжаться своими ресурсами, богатствами и всей экономической деятельностью (верховенство государства внутри) и суверенное право государства на равноправное участие в межгосударственных отношениях (независимость государства вовне). При этом каждый из этих элементов имеет сложный нормативный комплекс более узкого содержания. Так, принцип уважения экономического суверенитета, конкретизируя основной принцип международного права, обладает самостоятельной нормативной основой и одновременно

17 Там же. С. 52.

18 Там же. С. 59. 
выступает как обобщающий более конкретные нормы (о неотъемлемом суверенитете над ресурсами, об экономической недискриминации, о взаимной выгоде).

Отметим, что И.П. Блищенко и Ж. Дориа под содержанием принципа уважения экономического суверенитета понимают сочетание в нем территориальных и функциональных суверенных прав. Территориальные права - это права, осуществляемые государствами на своей территории, исходя из своего суверенитета, а функциональные суверенные права - применяемые государством на пространстве со смешанным режимом, то есть в исключительной экономической зоне и на континентальном шельфе. У нас вызывает интерес, а разве ресурсы функциональных пространств не являются объектами экономической деятельности? Да, являются, к тому же это подтверждается самими авторами ${ }^{19}$ ссылкой на регулирование указанных объектов принципом неотъемлемого суверенитета над природными ресурсами, богатствами и всей экономической деятельностью в целом, а также нормами других отраслей международного права. Тогда почему не ставить вопрос о существовании якобы «воздушного», «морского», «экологического» и т.д. суверенитетов и рассматривать, в частности, суверенитет над биологическими ресурсами не как проявление принципа уважения суверенитета государства как такового в конкретной области международных отношений, а в качестве составной части так называемого «экологического» суверенитета?

На наш взгляд, наиболее приемлемым было бы говорить о принципе уважения государственного суверенитета как об общей основополагающей норме международного права - принципе, а применительно к МЭП использовать понятие специального принципа «неотъемлемого суверенитета государств над природными ресурсами, богатствами и всей экономической деятельностью на своей территории» так, как он закреплен в Хартии 1974 г., Декларации о НМЭП и Хартии «О постоянном суверенитете над естественными ресурсами» 1962 г. и других документах.

Что же касается аргументации цитируемых авторов в пользу их позиции, основанной на обращении к территориям со смешанным режимом, то здесь, как отмечается ими самими, следует говорить о суверенных правах прибрежных государств на ресурсы и всю экономическую деятельность, с ними связанную, так как правовой режим ресурсов на этих территориях определяется не только нормами национального

19 Там же. С. 61. 
права, но и права международного. Тогда по-прежнему неясно, почему принцип неотъемлемого суверенитета над ресурсами и экономической деятельностью авторы включают в качестве одного из элементов в понятие «экономический суверенитет», а суверенные права прибрежных государств на ресурсы и всю экономическую деятельность на территориях со смешанным режимом не охватываются указанным понятием? Как можно говорить об экономическом суверенитете, если налицо суверенитет государства как таковой, нашедший применение в соответствующей сфере регулирования межгосударственных экономических отношений? Ведь речь идет о суверенных правах государств, независимо от того, осуществляются они на собственной территории или на территории со смешанным режимом.

Помимо этого, нельзя согласиться и с включением в качестве одного из элементов категории так называемого «экономического» суверенитета суверенного права государств на равноправное участие в межгосударственных экономических отношениях, поскольку последнее является конкретизацией основного принципа международного права, имеющего самостоятельное значение и направленного на укрепление государственного суверенитета.

Исходя из изложенного, необходимо сделать вывод, что суверенитет - это целостное юридическое понятие, а применительно к области регулирования МЭП следует говорить о суверенитете государства над естественными ресурсами и экономической деятельностью как конкретизирующем общепризнанный принцип уважения государственного суверенитета, а именно о правах государства, вытекающих из национального суверенитета, при осуществлении конкретной деятельности в той или иной сфере (внутренний аспект). Исходя из определения суверенитета (верховенство внутри страны и независимость на международной арене), в качестве внутригосударственного аспекта выступает свобода выбора форм организации внешнеэкономических связей, а определенной составляющей независимости вовне - свобода выбора форм участия в международном разделении труда, специализации и кооперировании производства, товарного обмена и т.д. Выступление данного принципа в качестве необходимой конкретизации императивного основного принципа международного права, позволяет говорить о его обязательной силе 20.

${ }^{20}$ Например, Г. Шварценбергер не только признает императивность исследуемого принципа, но и трактует в целом Резолюцию Генеральной Ассамблеи ООН от 12 декабря 
Подобной позиции придерживается большинство ученых, однако их аргументы в обоснование юридической силы указанных резолюций отличаются.

Так, в семитомном Курсе международного права 21 отмечается, что резолюции, подтверждающие или конкретизирующие положения Устава ООН, приобретают обязательную силу для членов ООН, поскольку такие резолюции выходят за рамки обычных рекомендаций.

Как отмечает Г. Е. Бувайлик, «выполняя свои полномочия, Генеральная Ассамблея ООН вправе принимать решения, направленные не только на необходимость соблюдения во взаимоотношениях государств-членов основных принципов международного права, закрепленных в Уставе, но и решения, детализирующие и конкретизирующие эти принципы с целью международно-правового регулирования взаимоотношений членов ООН в определенных областях, включая область международных экономических отношений. Государства - члены $\mathrm{OOH}$, ратифицировав Устав, взяли на себя договорные обязательства соблюдать эти принципы в регулировании их взаимоотношений во всех областях. Более того, каждое государство - член ООН, взяв на себя обязательство соблюдать принципы Устава ООН, обязано признать и все вытекающие из них действующие принципы и нормы международного права» ${ }^{22}$. Таким образом, автор признает обязательную силу резолюций, которые подтверждают принципы Устава Организации Объединенных Наций и конкретизируют их действующими в международном праве принципами и нормами применительно к регулированию

1962 г., как јus cogens (см.: Schwarzenberger G. Economic world order?: a basic problem of international economic law. Manchester, 1970. P. 41; см. также: Higgins R. Conflict of interests. International law in a divided World. London, 1965, p. 54; Kronfol Z. Protection of Foreign investment. A study in International Law, A.W. Sijthoff. Leiden, 1972, p. 22).

${ }^{21}$ Курс международного права. Т. 1. С. 192, 194. Данная позиция прослеживается и в работах ряда советских авторов, но с некоторыми дополнениями и оговорками, связанными с результатами голосования таких резолюций на сессиях Генеральной Ассамблеи. См.: Морозов Г.И. Международные организации. Некоторые вопросы теории. М., 1974. С. 279 - 280; Фельдман Д. И., Яновский М.В. Генеральная Ассамблея ООН и вопросы развития международного права. Казань, 1968. С. 188-191.

${ }^{22}$ Бувайлик Г. Е. Правовое регулирование международных экономических отношений. Киев. «Наукова думка», 1977. С. 263. См. также: Ашавский Б.М. К вопросу о международном экономическом праве//Советский ежегодник международного права. 1984. - М.: Наука, 1986. С. 42 . Он же. Международное экономическое право как формирующаяся отрасль международного права//Актуальные международно-правовые проблемы. Сборник статей. 2001. С. 21-22. 
международных экономических отношений. Все другие резолюции, по его мнению, не конкретизирующие или не подтверждающие принципов Устава ООН, являются для государств - членов ООН лишь рекомендациями. Рекомендациями являются и резолюции, содержащие новые принципы и нормы международного права, которые могут приобретать обязательную силу для каждого члена ООН в случае их признания в соответствующем порядке. Иной подход к оценке юридической силы рассматриваемой категории резолюций Генеральной Ассамблеи и ЮНКТАД может лишь тормозить общую перестройку современных международных экономических отношений на демократической и равноправной основе.

М.М. Богуславский подчеркивает юридическую силу резолюцийрекомендаций международных организаций, т.к. эти акты содержат определенный юридический элемент и могут играть важную роль, часто не уступающую роли норм международного права. Автор отмечает также, что распространение принципов и норм современного международного права на сферу, в частности, международного экономического права представляет собой тенденцию универсализма, поэтому принципы и нормы МЭП носят универсальный характер 23.

Отдельные авторы, придерживаясь соответствующей позиции, обосновывают обязательность указанных актов, в частности Хартии, ссылкой на ст. 56 Устава ООН, согласно которой «все члены организации обязуются предпринимать совместные и самостоятельные действия в сотрудничестве с Организацией для достижения целей, указанных в ст. $55 »^{24}$.

Ряд специалистов ищут подтверждение правовой силы решений Генеральной Ассамблеи ООН в области развития правового регулирования международных экономических отношений не в Уставе $\mathrm{OOH}$, а в некой особой технике (или методе) создания норм НМЭП, якобы характерной для международного экономического права и заключающейся не в традиционной концепции согласия, а в концепции консенсуса ${ }^{25}$.

Д. Яннопулос, при рассмотрении вопроса о подготовке текста Хартии экономических прав и обязанностей государств отмечал, что вос-

23 Богуславский М. М. Международное экономическое право М.: Междунар. отношения, 1986. С. 31.

${ }^{24}$ Bulagic M. Legal aspects of a new international economic order. World Peace Through Law Center, 1979. P. 98.

${ }^{25}$ Shinya M. International law - making for NIEO // Japanese yearbook of international law. Tokio, 1983. P. 65. 
произведение в этом документе принципов Устава ООН означает лишь применение их в регулировании не только политических, но и экономических взаимоотношений государств. Более существенное значение, подчеркивает Д. Яннопулос, состоит в том, если будет предпринята попытка «выделить из этих принципов ряд конкретных норм, применение которых рассматривается подавляющим большинством государств желательным в регулировании международных экономических отношений» 26 . Таким образом, эффективное применение общепризнанных принципов государствами-членами ООН возможно лишь путем соблюдения ими конкретных международно-правовых норм, вытекающих из этих принципов.

Оценивая значение Хельсинкского акта в системе международно-правового регулирования, Г.В. Игнатенко пишет: «При изложении в акте принципа добросовестного выполнения обязательств по международному праву государства-участники заявили, в частности, что будут «учитывать должным образом и выполнять» положения самого Заключительного акта. Следовательно, положения этого документа официально признаны всеми государствами-участниками в качестве составной части действующего международного права» ${ }^{27}$. Данная позиция перекликается с позициями других авторов, которые, рассматривая резолюции Генеральной Ассамблеи в качестве источника международного права, также признают их обязательное значение при условии непротиворечия Уставу ООН и основным принципам международного права и принятия единогласно или большинством голосов, поскольку в них выражена согласованная воля государств 28.

Ряд западных авторов также признают императивный характер принципов МЭП, содержащихся в резолюциях, развивающих основные принципы международного права ${ }^{29}$. Так, А. Альварес относит резолю-

${ }^{26}$ Yannopoulos D. Premiers effects pour une Charte des droits et des devoirs économiques des Etats // Revue belge de droit international. Ed. De l'Université de Bruxelles, vol. 1, $1974-2 /$ P. 513.

${ }^{27}$ Игнатенко Г. В. Заключительный акт общеевропейского совещания в Хельсинки. «Правоведение», 1976, № 3. С. 102.

${ }_{28}^{28}$ Минасян Н.М. Право мирного сосуществования. Ростов н/Д, 1966. С. 234-235; Морозов Г.И. Организация Объединенных Наций. М., 1962. С. 217-218.

${ }^{29}$ См.: Xydis S. G. The General Assembly. - In: The United Nations. Past, present and future. Ed. by J. Barros. N. Y. Free press, L. Collier - Macmillan, 1972, p. 64 - 103; Bestelier R. Le droit international economique et le nouvel ordre economic international // Rev. roum. etud. intern. 1984. Mars-avr. P. 151. 
ции, подтверждающие и развивающие принципы Устава ООН, к обязательным для всех государств ${ }^{30}$.

Таким образом, принципы, закрепленные в перечисленных и иных международных документах, являются критерием правомерности экономических договоров и соглашений, заключаемых государствами в различных областях международных экономических отношений, то есть государства - члены ООН не вправе при заключении соответствующих экономических договоров и соглашений отступать от основных принципов и норм международного права, конкретизированных применительно к регулированию международных экономических отношений (специальных принципов МЭП).

К третьей группе относятся ученые, отрицающие правовую силу названных международных актов. Свою позицию они обосновывают ссылкой на ст. 10 Устава ООН, предусматривающей рекомендательный характер резолюций Генеральной Ассамблеи ООН (как и ЮНКТАД, и ЮНИДО). Так, Я. Броунли отмечает, что Хартия не может считаться декларацией ранее существовавших принципов и в целом имеет прагматический, политический и дидактический характер ${ }^{31}$. Они создают основу для прогрессивного развития права и скорейшего объединения норм обычного права. Однако в отдельных случаях резолюция, в частности Декларация «О постоянном суверенитете над природными ресурсами», может иметь юридическую силу в качестве авторитетного толкования и применения принципов Устава. В целом каждая отдельная резолюция должна оцениваться в свете всех обстоятельств, а также путем ссылки на другие доказательства, предусматривающие мнения государств по данному вопросу 32 .

Ханс ван Хут, признавая необязательный характер резолюций ГА ООН, отмечает их значительную роль в создании обычного международного права ${ }^{33}$.

В семитомном Курсе международного права отмечается, что в связи с вопросом о правовой силе Декларации, Программы и главным

${ }^{30}$ Alvarez A. Le droit international nouveau dans ses rapports avec la vie actuelle des peoples. Paris, 1959, p. 424.

${ }^{31}$ Brownlie I. Legal status of natural resources in International Law (Some aspects) // Rec. cours. 1979. T. 1. P. 295. См. также: J.P. Cot \& A. Pellet. La Charte des Nations Unies (Economica, 1991, Paris. P. 252.

${ }^{32}$ Brownlie I. Principles of public international law. Sixth edition. Oxford University Press. 2003. P. 15.

${ }^{33}$ The law of international trade by Hans van Houtte. London. Sweet \& Maxwell. 1995. P. 11. 
образом Хартии появились высказывания о некоем «новом» праве, не имеющем обязательной силы, которое в доктрине обозначено различными терминами, а в общем понимается как «мягкое право». Мягкое право - это неправовое явление, нормы которого не являются юридически обязательными; они устанавливают правила поведения государств в тех или иных областях, но их несоблюдение не влечет за собой юридической ответственности. Впрочем, иногда обязанность исполнять норму формально существует, но она не подкреплена фактическим механизмом исполнения нормы, а также наличием критериев подобного исполнения, например, если речь идет об основных принципах международного права, так как их соблюдение обязательно для всех государств. Нормы «мягкого права» могут оперативно реагировать на происходящие изменения, поскольку не требуют сложной процедуры принятия и внесения изменений. Подобное свойство весьма значимо для МЭП в связи с динамично изменяющимися и развивающимися международными экономическими отношениями. К тому же «мягкие» нормы могут впоследствии трансформироваться в «классическую» правовую норму путем закрепления в международных договорах или формирования обычно-правовых норм международного права.

Так, на возможность приобретения специальными принципами МЭП, носящими рекомендательный характер, характера облигаторного в случае их конвенционного закрепления, указывает и Г.М. Вельяминов ${ }^{34}$.

По мнению австрийского профессора И. Зайдль-Хохенфельдерна ${ }^{35}$, отстаивающего концепцию международного экономического «мягкого права», принципы и нормы МЭП обладают необязательным характером. Автор исходит из того, что нормы отрасли международного экономического права неточны, расплывчаты и не налагают обязательств на государства, а также из рекомендательных положений резолюций международных организаций в рассматриваемой области.

Против концепции «мягкого права» возражает и итальянский ученый Г. Аранжио-Руне, указывая, что совмещением определения «мягкое» с понятием «право» создается противоречие. Если «мягкое» означает «необязательное», то можно определить право как - «твердое».

\footnotetext{
${ }^{34}$ Вельяминов Г. М. Международное экономическое право и процесс. С. 136.

${ }^{35}$ Seidl-Hohenveldern I. International economic "soft law". - Rec. cours. Collected courses of the Hague Academy of international law, 1979 - II, 1980, t. 163, p. 165 - 246.
} 
«Любое право, не являющееся твердым, просто не есть право вообще или не есть еще право» ${ }^{36}$.

С.А. Войтович, не признавая обязательную силу специальных принципов МЭП, выступает, однако, за наделение этих принципов когентным характером путем расширения двусторонней договорной практики, что способствовало бы формированию общепризнанных отраслевых принципов МЭП в форме международно-правового обычая, а также нормативное их закрепление в многосторонних договорах между государствами ${ }^{37}$.

Исследование позиций различных авторов отечественной и зарубежной международно-правовой науки позволяет говорить о признании большей частью международно-правовой доктрины императивного характера принципов и норм МЭП, содержащихся в решениях Генеральной Ассамблеи ООН, ЮНКТАД, ЮНИДО, так как, несмотря на то, что резолюции международных организаций по своей сути являются всего лишь рекомендациями, закрепленные в них положения, регулирующие международные экономические отношения, представляют собой конкретизацию и развитие основных общепризнанных принципов Устава ООН за счет применения в специальных областях и имеющих обязательную силу для государств, вследствие чего принципы международного экономического права определяют регламентацию практической экономической деятельности государств между собой. К тому же большинство принципов МЭП нашли свое закрепление в обычных международно-правовых нормах, и их юридическая обязательность вытекает из международной практики, которая существовала как до принятия названных актов, так и после их принятия.

\section{Библиографический список.}

Ануфриева Л.П., Спектор А.А. Принцип национального режима в регулировании международной торговли//СПС Консультант Плюс.

Ашавский Б.М. Международное экономическое право как формирующаяся отрасль международного права//Актуальные международно-правовые проблемы. Сборник статей. 2001.

\footnotetext{
${ }^{36}$ Цит. по: Колодкин Р. А. Критика концепции «мягкого права» // Советское государство и правою 1985. № 12. С. 98.

${ }^{37}$ Войтович С. А.Роль международно-правовых принципов в формировании международного экономического права // Вестник киевского университета. Международные отношения и международное право. - Киев: Вища шк., 1978, № 15. С. 33.
} 
Ашавский Б.М. К вопросу о международном экономическом праве// Советский ежегодник международного права. 1984. - М.: Наука, 1986.

Блищенко И.П., Дориа Ж. Экономический суверенитет государства: Учебное пособие. - М.: Изд-во РУДН, 2001.

Богуславский М.М. Международное экономическое право М.: Междунар. отношения, 1986.

Бувайлик Г.Е. Правовое регулирование международных экономических отношений. Киев. «Наукова думка», 1977.

Вельяминов Г.М. Международное экономическое право и процесс. (Академический курс): Учебник - М.: Волтерс Клувер, 2004.

Войтович С.А. Роль международно-правовых принципов в формировании международного экономического права // Вестник киевского университета. Международные отношения и международное право. Киев: Вища шк., 1978, № 15.

Иванов И.М. Международно-правовое содержание экономического суверенитета//Евразийский юридический журнал. 2009, № 8 .

Игнатенко Г.В. Заключительный акт общеевропейского совещания в Хельсинки. - «Правоведение», 1976, № 3.

Избулатов Х.Х. Экономический суверенитет России в условиях нового геополитического порядка: Юридические формы реализации. Автореферат диссертации на соискание ученой степени кандидата юридических наук. Ростов-на-Дону, 2007.

Колодкин Р.А. Критика концепции «мягкого права» // Советское государство и право. 1985. № 12.

Кузьмин Э. Л. Международное экономическое право: учебн. пособие. М., 2008.

Курс международного права. В 7 т. Т. 1, 2. М.: Наука, 1989.

Малинин С.А. Совещание в Хельсинки (1975 г.) и международное право. - «Правоведение», 1976, № 2.

Мамедов Р.Ф., Абиев Р.С. Международно-правовые принципы реализации экономического суверенитета Азербайджанской республики // Евразийский юридический журнал. № 4 (11), 2009.

Международное публичное право / отв. ред. К.А. Бекяшев. М., 2004.

Морозов Г.И. Международные организации. Некоторые вопросы теории. М., 1974.

Фельдман Д.И., Яновский М.В. Генеральная Ассамблея ООН и вопросы развития международного права. Казань, 1968. 
Собакин В.К. Итоги Совещания по безопасности и сотрудничеству в Европе и международное право. - XIX Ежегодное собрание Советской ассоциации международного права. Тезисы докладов. М., 1976.

Шумилов В.М. Введение в российскую научную концепцию международного экономического права// Юрист - международник. 2003. № 1.

Шумилов В.М. Международно-правовое регулирование международных экономических отношений (Вопросы теории и практики) // Государство и право. 2000. № 7.

Шумилов В.М. Международное экономическое право. Учебник. Ростов-н/Д.: Феникс, 2003.

Alvarez A. Le droit international nouveau dans ses rapports avec la vie actuelle des peoples. Paris, 1959.

Bestelier R. Le droit international economique et le nouvel ordre economic international // Rev. roum. etud. intern. 1984. Mars-avr.

Brownli I. Principles of public international law. Sixth edition. Oxford University Press. 2003.

Brownlie I. Legal status of natural resources in International Law (Some aspects) // Rec. cours. 1979. T. 1.

Bulagic M. Legal aspects of a new international economic order. World Peace Through Law Center, 1979.

Higgins R. Conflict of interests. International law in a divided World. London, 1965.

International Business Transactions. Problems, Cases and Materials. D. C. K. Chow, T.J. Schoenbaum. NY. 2005.

International Economic Law. Second edition. Andreas F. Lowenfeld. Oxford University Press, 2008.

Kronfol Z. Protection of Foreign investment. A study in International Law, A. W. Sijthoff. Leiden, 1972.

New directions in International Economic Law. Essays in honour of John H. Jackson. Kluwer Law International. The Hague/London/Boston. 2000.

Schwarzenberger G. Economic world order? A basic problem of international economic law. Manchester, 1970.

Seidl-Hohenveldern I. International economic "soft law". - Rec. cours. Collected courses of the Hague Academy of international law, 1979 - II, 1980, t. 163.

Shinya M. International law - making for NIEO // Japanese yearbook of international law. Tokio, 1983. 
Sources of International Law. Martti Koskenniemi. University of Helsinki. 2000.

The law of international trade by Hans van Houtte. London. Sweet \& Maxwell. 1995.

Xydis S. G. The General Assembly. - In: The United Nations. Past, present and future. Ed. by J. Barros. N. Y. Free press, L. Collier - Macmillan, 1972.

Yannopoulos D. Premiers effects pour une Charte des droits et des devoirs économiques des Etats // Revue belge de droit international. Ed. De l’Université de Bruxelles, vol. 1, 1974. 


\section{Concept of Principles of International Economic Law \\ (Summary)}

\section{Indira S. Chabaeva*}

This article relates to disclosure of the concept of principles of international economic law. Domestic and foreign authors' approaches on how to treat principles of international economic law as legal regimes and standards, as well as some arguments regarding the impossibility of such treatment are presented there. A list of principles of the international economic law, which is not exhaustive, as well as international documents, which set forth or specify the principles under the question, are given. The question of legal availability in the treaties of the category of "economic sovereignty" became the subject matter under analysis. Current positions on recognition of a legal binding or, in contrast, non-binding nature of these documents and, as a result, statements related to the «soft law», which is indicated by different terms in doctrine, as well as the question of whether the principles of international economic law consolidated in these documents to be considered as mandatory, are reflected. The question relating to the forms of legal existence of the principles of international economic law with regards to external forms of expression, i.e. international treaty and international custom is perused.

Keywords: concept of principles of international economic law; custom rules and treaty rules; international instruments bearing the principles of international economic law and related to the problem of their legal force.

\footnotetext{
* Indira S. Chabaeva - post-graduate student of the International law department of the Moscow State Law Academy. INDIRA.CHABAEVA@ya.ru.
} 